University of Rhode Island

DigitalCommons@URI

The Rhode Island Current Conditions Index

Economics

8-2013

\title{
Rhode Island Current Conditions Index - August 2013
}

Leonard Lardaro

University of Rhode Island, lardaro@uri.edu

Follow this and additional works at: https://digitalcommons.uri.edu/ricci

Part of the Econometrics Commons

Terms of Use

All rights reserved under copyright.

\section{Recommended Citation}

Lardaro, Leonard, "Rhode Island Current Conditions Index -- August 2013" (2013). The Rhode Island Current Conditions Index. Paper 90.

https://digitalcommons.uri.edu/ricci/90

This Article is brought to you for free and open access by the Economics at DigitalCommons@URI. It has been accepted for inclusion in The Rhode Island Current Conditions Index by an authorized administrator of DigitalCommons@URI.For more information, please contact digitalcommons-group@uri.edu. 


\section{CURRENT CONDITIONS}

LEONARD LARDARO, URI

\section{Available Online: http:/ / www.llardaro.com/ current.htm (NEW URL) Blog: http:/ / rieconomy.blogspot.com}

VOL XX NUMBER 9 AUG 2013
As the third quarter progresses, there is both good news and bad news about the performance of Rhode Island's economy. The good news is that the July Current Conditions Index's value was revised higher, from 75 to 83 . The bad news is that the $\mathrm{CCl}$ for August declined to 67 , as only eight of twelve indicators improved relative to their values one year ago. Furthermore, August was only the second month this year for which the $\mathrm{CCl}$ failed to exceed its year-earlier value (J une was the other). My primary concern moving forward, which I have written about for several months now, is that the $\mathrm{CCl}$ for the remainder of this year will very likely fail to beat last year's values, which would reflect a clear slowdown in our rate of growth relative to the end of last year. This should not come as a complete surprise given the clear acceleration in the pace of economic activity for Rhode Island as 2012 came to an end. Sadly, but not surprisingly, the combination of fiscal drag from Washington and the government shutdown should only make these yearly divergences worse.

At times like this it is informative to look at the performance of the leading indicators contained in the $\mathrm{CCl}$. For August, all four of these had difficult "comps" from a year ago. Only two, however, were able to improve relative to those comps. Don't expect this to be the last time we encounter this phenomenon.

Let me reiterate an important point that will become ever-more relevant that is related to the seeming paradox of how our state's economy can be showing good momentum yet fail to return to where it was in 2006 and 2007. Current levels of economic activity depend on both the rates of growth we are experiencing and the prior activity levels themselves. Rhode Island's economy was extremely hard hit during The Great Recession, so, when our recent rates of growth are applied to these depressed activity

\begin{tabular}{|l|r|r|}
\hline \multicolumn{3}{|c|}{ CCI Indicators - \% Change } \\
\hline Government Employment & 0.7 & Y \\
\hline US Consumer Sentiment & 10.7 & Y \\
\hline Single-Unit Permits & -1.0 & \\
\hline Retail Sales & 6.2 & Y \\
\hline Employment Services Jobs & -2.1 & \\
\hline Priv. Serv-Prod Employment & 0.7 & Y \\
\hline Total Manufacturing Hours & 0.6 & Y \\
\hline Manufacturing Wage & 4.4 & Y \\
\hline Labor Force & -1.6 & \\
\hline Benefit Exhaustions & -18.2 & Y \\
\hline New Claims & 7.5 & \\
\hline Unemployment Rate (change) & -1.3 & Y \\
\hline \multicolumn{2}{|c|}{ Y = Improved Value } \\
\hline \multicolumn{2}{|l}{}
\end{tabular}

levels, we continue to see relatively small changes in the actual level of economic activity. As our rate of growth is slowing, it will now take even longer to return to where we were pre-recession.

As stated earlier, two of the $\mathrm{CCl}$ 's four leading indicators improved in August. The uptrend in Single-Unit Permits, a leading indicator of housing, continues, although this indicator failed to improve in August (last August its rate of growth was 34\%). In spite of this setback, Permits have now settled into a range of $70+$ each month. US Consumer Sentiment improved for the seventh consecutive month in August, rising 10.7 percent. Expect to see it began to weaken, given our nation's fiscal dysfunction.

The remaining leading indicators are related to the labor market. The first of these, Employment Service Jobs, which includes temporary employment, a prerequisite to overall employment growth, fell for the first time in over a year. It registered a decline of 2.1 percent relative to its 5 percent rise last August. While this indicator has generally improved since last April, its slowing rate of improvement coupled with an August decline calls into question whether it will sustain its uptrend. New Claims for Unemployment Insurance, the most timely measure of layoffs, appears to now be in an uptrend (note: we want this to decline), as it has now risen for five of the last seven months. A trend of rising layoffs will adversely affect other $\mathrm{CCl}$ indicators in coming months, most notably Retail Sales. The final leading indicator, Total Manufacturing Hours, which measures strength in our manufacturing sector, barely rose (by $0.6 \%$ ). Its recent performance has been spotty in light of stronger global economies that boost exports and a weakening US economy.

Retail Sales remained strong, growing at 6.2 percent relative to last August (which had a $9 \%$ improvement). Private Service-Producing Employment growth remained below one percent (that could be faulty data). Our state's Labor Force declined again (the fifth time), but was distorted by seasonal adjustment problems concerning students. Our Unemployment Rate notched higher over the month, as the Manufacturing Wage rose by "only" 4.4 percent. Finally, Government Employment rose for the first time in quite a while.

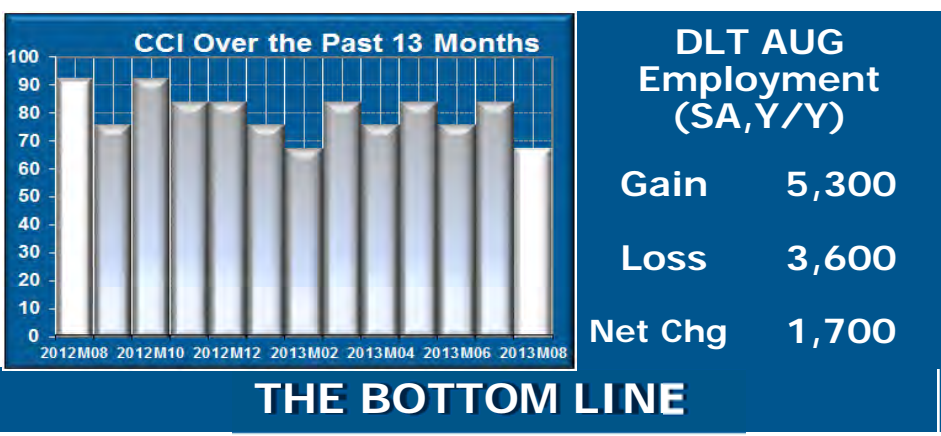

In all likelihood, the third quarter will mark the inflection point for the rate of growth in Rhode Island's economy. August was the second month for which the $\mathrm{CCl}$ failed to beat its year-earlier value. It is not unreasonable to expect this pattern to recur for the remainder of 2013. Add federal fiscal dysfunction to our state long-term fiscal nonfunction and the result is hardly encouraging. Let's hope Rhode Island's Secretary of Commerce, whoever that is, will be every bit the superhero that the job description for that position requires!

\begin{tabular}{|c|c|c|c|c|c|c|c|c|c|c|c|c|c|}
\hline & & Jan & Feb & Mar & Apr & May & J un & Jul & Aug & Sep & Oct & Nov & Dec \\
\cline { 2 - 13 } & 2012 & $67 \uparrow$ & $58 \uparrow$ & 58 & $67 \uparrow$ & $67 \uparrow$ & $83 \uparrow$ & $58 \uparrow$ & $92 \uparrow$ & $75 \uparrow$ & $92 \uparrow$ & $83 \uparrow$ & $83 \downarrow$ \\
\cline { 2 - 12 } & 2013 & 75 & 67 & 83 & $75 \uparrow$ & 83 & 75 & $83 \uparrow$ & 67 & & & & \\
\hline
\end{tabular}

